\title{
Overview of Mycelial Fungi - Lignin Destructors
}

Ivanova Lyudmila Afanasevna ${ }^{1}$, Fomenkolvan Andreevich ${ }^{1}$, Churmasova Lyudmila Alekseevna1, and Kuzmicheva Tatyana Pavlovna

Moscow State University of Food Production

ORCID:

Kuzmicheva Tatyana Pavlovna; 0000-0003-2478-1705

Abstract. In this work, the following genuses of mycelial fungi, capable of producing ligninolytic enzymes of various actions, were considered:Penicillium, Aspergillus, Fusariumand Altermaria. Fungi of the genus Aspergilluswere capable of producing laccase, manganese peroxidase and lignin peroxidase in the medium. Penicillium mostly produced laccase. Fusariumproduced laccase, aryl alcohol oxidase, manganesedependent peroxidase, manganese-independent peroxidase and lignin peroxidase. Alternariaproduced laccase, lignin peroxidase and manganese peroxidase. The results demonstrated the possibility of using specific substrates in the study of enzyme activity,

Corresponding Author: Kuzmicheva Tatyana Pavlovna; email: tania014454612@mail.ru

\section{Dates}

Published 13 January 2022

Publishing services provided by Knowledge E

(c) Ivanova Lyudmila Afanasevna et al. This article is distributed under the terms of the Commons Attribution License, which permits unrestricted use and redistribution provided that the original author and source are credited.

Selection and Peer-review under the responsibility of the 8 th Scientific and Practical Conference Conference Committee. as well as the influence of some factors introduced into the medium on the synthesis of enzymes. The auxiliary influence of these fungi on the synthesis of ligninolytic enzymes in symbiosis with otherswas considered.

Keywords: mycelial fungi, ligninolytic enzymes, Penicillium, Aspergillus, Fusarium, Altermaria

\section{Modern concepts of lignin}

Lignin is one of the main components of plant tissues in quantitative terms. Its content can be up to $30 \%$ dry matter.Being formed in large quantities and undergoing slow biodegradation and difficult acid breakdown, lignin makes it difficult to process wood and prevents the release and hydrolysis of substances such as cellulose, hemicellulose and others. This reduces the efficiency and increases the costs of enterprises in various industries. In addition, due to the harsh conditions of the lignin extraction process, partial depolymerization and chemical modification of the initial polymer occurs.

In the modern view, the lignin molecule represents itself as a redox polymer built from arylpropane structural units. The polymer is formed by oxidative combination of monolignols, among which there are three main hydroxycinnamic alcohols: n-coumaric, coniferyl, and sinapyl.Their ratio is the difference between lignin of different tree species.

\section{S OPEN ACCESS}




\section{Producers of lignin destructor enzymes}

The ability of basidiomycetes to grow on decaying trees is widely known due to the production of complex enzymes that act on native lignin, as a result of which white or brown rot is formed on its surface. However, more and more studies have recently appeared aimed at studying the ability of microscopic mycelial fungi to synthesize various enzymes of the ligninase complex, which include lignin peroxidase (LiP), manganese-dependent peroxidase (MnP), phenol oxidizing enzymes and hydrogen peroxide-generating enzymes. The most famous genuses of such microorganisms are Ascomycetes and Deuteromycetes: Penicillium, Aspergillus, Trichoderma and Fusarium, Altermaria, respectively.

\subsection{Fungi of the genus Aspergillus}

In fungi of the species Aspergillus flavum, the formation of such enzymes as lignin peroxidases, laccase, polyphenol oxidasewas noted.At the same time, the fungal strain isolated in the study [6], causing selective degradation of lignin in agricultural lignocelIulosic waste, does not affect the cellulose content. In the experiment carried out, the activity of lignin peroxidase was $2,5 \mathrm{U} / \mathrm{ml}$.

Aspergillus niger is also referred to as a producer of laccase, peroxide manganese and lignin peroxidase. In the study [17], the production of enzymes was optimized, the activity of which was $9023,67 \mathrm{UI} / \mathrm{L}$ for laccase, $2234,75 \mathrm{UI} / \mathrm{L}$ for lignin peroxidase, and $8534,81 \mathrm{UI} / \mathrm{L}$ for manganese peroxidase.

In addition to agricultural waste substrates containing lignin, which include, for example, wheat straw, corncobs [12], palm cactus husk [17], artificially synthesized "model" compounds that resemble parts of the proposed formula of native lignin can also be used for research.Thus, in the article [2], the biodegradation of the azo dye malachite green (MG) using the culture of the fungus Aspergillus flavus (F10), which secretes laccase and manganese peroxidases, was considered, as a result of which discoloration of the substrate is observed.It is worth noting the difference in temperature and $\mathrm{pH}$ optima for the accumulation of a specific enzyme from this type offungy: for laccase(Lac)it is $7,5 \mathrm{pH}$ and $15{ }^{\circ} \mathrm{C}$. For LiP and MnP, the $\mathrm{pH}$ is 7,5-9,5 and 5,5-9,5 and 25 and $35{ }^{\circ} \mathrm{C}$, respectively [4]. The introduction of sodium nitrate into the medium can induce their synthesis $[1,2]$.

Aspergillus fumigatus and Aspergillus terreus are also mentioned as producers of ligninase enzymes $[1,8,15,16]$. The latter, during solid-phase cultivation, can give out the 
specific activity of enzymes equal to $0.83 \mathrm{U} / \mathrm{mg}$ for manganese peroxidase, 18,03 U / $\mathrm{mg}$ for lignin peroxidase and 0,91 U / mg for laccase without additional purification.

\subsection{Fungi of the genus Penicillium}

In the case of fungi of this genus, they most often speak of the laccase activity of its enzymes. In a study [14] with a Penicillium chrysogenum strain on media containing various dyes, neither lignin peroxidase, nor manganese-dependent peroxidase, nor aryl alcohol oxidase were detected. Laccase activity was also studied for Penicillium simplicissimum $\mathrm{H} 5$ during solid-phase fermentation with rice straw [19].

\subsection{Fungi of the genus Fusarium}

Fusarium solani strains are capable of producing laccases, aryl alcohol oxidase [13], manganese-dependent peroxidase and manganese-independent peroxidase (MIP), and lignin peroxidase. The activity of laccase can be more than 8,6 $\mathrm{mU} / \mathrm{ml}[10], \mathrm{MnP}-9,43$ $\mathrm{U} / \mathrm{ml}$, LiP -33,06 U / ml [11].

Reactive oxygen species are involved in lignin degradation. This was proved by introducing scavengers of superoxide and hydroxyl radicals into the medium with the culture of Fusarium proliferatum, which led to a decrease in the rate and efficiency of lignolysis [13].

\subsection{Fungi of the genus Alternaria}

They are capable of producing laccases [7,18], lignin peroxidase, manganese peroxidase [9].Sucrose [2, 18], aromatic alcohols (veratryl alcohol) $[10,18]$ can act as an inducer of laccase synthesis.

In the study [9], five fungal isolates Alternaria alternata, Alternaria sp. PMK1, Alternaria sp. PMK2, Alternaria macrospora MKP2, and Alternaria macrospora MKP4 showed the following maximum activities of ligninase complexes: laccase from Alternaria $s p$. PMK2 - 26,50 U / ml, lignin peroxidase ofAlternaria macrospora MKP2 - 0,25 U / ml, manganese-dependent peroxidase from Alternaria sp.PMK2 - 0,3 U / ml. 


\section{Combined action of fungi - lignin destructors}

Some studies are aimed at studying the joint inducing effect of fungi on the synthesis of ligninolytic enzymes. $T$. viride and $A$. terreus were recognized as the best inducers of Leptosphaerulina sp., as evidenced by the more efficient removal of the Reactive Black 5 dye as compared to monoculture [3].

The addition of Trichoderma reesei to the culture of Coprinus comatus in a ratio of 2: 5 makes it possible to increase the activity of the laccase enzyme by $106 \%$ in comparison with the cultivation of a monoculture of Basidiomycete [5]. The laccase activity in this study reached $3267,1 \mathrm{U} / \mathrm{ml}$.

\section{Conclusion}

Microscopic filamentous fungi of different genusesare capable of synthesizing ligninolytic enzymes, and the rate of their reproduction is higher than that of the latter, which prompts scientists to look for new more effective strains or create complexes of various groups of fungi, as well as modify the methods of their cultivation and study.

\section{References}

[1] Ali MIA, Khalil NM, Abd El-Ghany MN. Biodegradation of some polycyclic aromatic hydrocarbons by Aspergillus terreus.African Journal of Microbiology Research.2012;6(16):3783-3790.

[2] Barapatre A, Aadil KR, Jha H. Biodegradation of malachite green by the ligninolytic fungus Aspergillus flavus.Clear: Soil, Air, Water. 2017;45(4). 218-225

[3] Copete-Pertuz LS, Alandete-Novoa F, Plácido J, Correa-Londoño GA, Mora-Martínez AL. Enhancement of ligninolytic enzymes production and decolourising activity in Leptosphaerulina sp. by co-cultivation with Trichoderma viride and Aspergillus terreus. Science of The Total Environment. 2019;646:1536-1545.

[4] Dhakar K, Kooliyottil R, Joshi A, Pandey A. Simultaneous production of ligninolytic enzymes by a temperature and $\mathrm{pH}$ tolerant strain of Aspergillus niger under different cultural conditions. Indian Journal of Biotechnology 2015;14(1):81-86.

[5] Ge C, Xu J, Sun Q, Zhang J, Cai J, Pan R. Production of ligninase by cofermentation of Coprinus comatus and Trichoderma reesei.Chinese Journal of Biotechnology.2009;25(12):2008-201. 
[6] Hasanina SM, Darwesh OM, Matter IA, El-Saieda H. Isolation and characterization of non-cellulolytic Aspergillus flavus EGYPTA5 exhibiting selective ligninolytic potential.Biocatalysis and Agricultural Biotechnology. 2019, 17:160-167.

[7] Irfan M, Mehmood S, Irshad M, Anwar Z. Optimized production, purification and molecular characterization of fungal laccase through Alternaria alternata. Turkish Journal of Biochemistry . 2018;43(6):613-622.

[8] Kanayama N, Suzuki T, Kawai K. Purification and characterization of an alkaline manganese peroxidase from Aspergillus terreus LD-1. Journal of Bioscience and Bioengineering. 2002;93(4):405-410.

[9] Kaur M, Aggarwal NK, Yadav A, Gupta R. Evaluation of ligninolytic activity of fungal pathogens isolated from parthenium weed.Zoology and Botany. 2016;4(2):23-29.

[10] SaparratNMC, Martínez MJ, Tournier HA, Cabello MN, Arambarri AM. Production of ligninolytic enzymes by Fusarium solani strains isolated from different substrata.World Journal of Microbiology and Biotechnology.2000;16:799-803.

[11] Obruca S, Marova I, Matouskova P, Haronikova A, Lichnova A. Production of lignocellulose-degrading enzymes employing Fusarium solani F-552.Folia Microbiologica. 2012;57:221-227.

[12] Pant D, Adholeya A. Enhanced production of ligninolytic enzymes and decolorization of molasses distillery wastewater by fungi under solid state fermentation.Biodegradation. 2007;18:647-659.

[13] Regalado V, Perestelo F, Rodríguez A et al. Activated oxygen species and two extracellular enzymes: Laccase and aryl-alcohol oxidase, novel for the lignindegrading fungus Fusarium proliferatum. Applied Microbiology and Biotechnology. 1999;51:388-390.

[14] Rodríguez A, Falcón MA, Carnicero A, Perestelo F, De la Fuente G, Trojanowski J. Laccase activities of Penicillium chrysogenum in relation to lignin degradation.Applied Microbiology and Biotechnology.1996;45:399-403.

[15] Sahar GI, Ghazi MA, NadaSR. Optimization of ligninolytic enzymes production from Aspergillus terreus SG-777 by solid state fermentation. Iraqi Journal of Veterinary Medicine. 2016;40(1):116-124.

[16] Sahoo KD, Gupta R. Evaluation of ligninolytic microorganisms for efficient decolorization of a small pulp and paper mill effluent. Process Biochemistry. 2005;40(5):1573-1578.

[17] Santos TC, Reis SN, Silva TP, Machado FPP, Bonomo RCF, Franco M. Prickly palm cactus husk as a raw material for production of ligninolytic enzymes by Aspergillus niger. Food Science and Biotechnology. 2016;25:205-211. 
[18] Thakkar AT, Bhatt SA.Isolation, identification and optimization of laccase from Alternaria alternata.Journal of Applied Biology \& Biotechnology.2020;8(3):64-69.

[19] Zeng GM, Yu HY, Huang HL et al. Laccase activities of a soil fungus Penicillium simplicissimum in relation to lignin degradation.World Journal of Microbiology and Biotechnology. 2006;22:317-324. 